\title{
New insights into atmospherically relevant reaction systems using direct analysis in real-time mass spectrometry (DART-MS)
}

\author{
Yue Zhao $^{1, \text { a }}$, Michelle C. Fairhurst ${ }^{1}$, Lisa M. Wingen ${ }^{1}$, Véronique Perraud ${ }^{1}$, Michael J. Ezell ${ }^{1}$, and \\ Barbara J. Finlayson-Pitts ${ }^{1}$ \\ ${ }^{1}$ Department of Chemistry, University of California, Irvine, CA 92697, USA \\ ${ }^{a}$ currently at: Department of Atmospheric Sciences, University of Washington, Seattle, WA 98195, USA \\ Correspondence to: Barbara J. Finlayson-Pitts (bjfinlay@uci.edu)
}

Received: 27 October 2016 - Discussion started: 29 November 2016

Revised: 8 March 2017 - Accepted: 9 March 2017 - Published: 11 April 2017

\begin{abstract}
The application of direct analysis in real-time mass spectrometry (DART-MS), which is finding increasing use in atmospheric chemistry, to two different laboratory model systems for airborne particles is investigated: (1) submicron $\mathrm{C}_{3}-\mathrm{C}_{7}$ dicarboxylic acid (diacid) particles reacted with gas-phase trimethylamine (TMA) or butylamine (BA) and (2) secondary organic aerosol (SOA) particles from the ozonolysis of $\alpha$-cedrene. The diacid particles exhibit a clear odd-even pattern in their chemical reactivity toward TMA and BA, with the odd-carbon diacid particles being substantially more reactive than even ones. The ratio of base to diacid in reacted particles, determined using known diacid-base mixtures, was compared to that measured by high-resolution time-of-flight aerosol mass spectrometry (HR-ToF-AMS), which vaporizes the whole particle. Results show that DART-MS probes $\sim 30 \mathrm{~nm}$ of the surface layer, consistent with other studies on different systems. For $\alpha$ cedrene SOA particles, it is shown that varying the temperature of the particle stream as it enters the DART-MS ionization region can distinguish between specific components with the same molecular mass but different vapor pressures. These results demonstrate the utility of DART-MS for (1) examining reactivity of heterogeneous model systems for atmospheric particles and (2) probing components of SOA particles based on volatility.
\end{abstract}

\section{Introduction}

Organic aerosol (OA) particles are responsible for $\sim 20$ $90 \%$ of atmospheric submicron particulate matter, with a substantial fraction being secondary organic aerosol (SOA) formed via oxidation of volatile organic compounds (Zhang et al., 2007; Jimenez et al., 2009; Hallquist et al., 2009; $\mathrm{Ng}$ et al., 2010; Finlayson-Pitts and Pitts, 2000). As a result, the chemistry and physics of OA particles have been of great interest to the atmospheric science community over decades. Despite significant progress, many physicochemical processes of OA particles, such as formation, growth, aging, and water uptake, remain to be quantitatively understood, which is essential for a better understanding of their impacts on air quality, human health, visibility, and climate (Kroll and Seinfeld, 2008; Hallquist et al., 2009; Laskin et al., 2015; Ziemann and Atkinson, 2012; Noziere et al., 2015; Glasius and Goldstein, 2016; George et al., 2015; Moise et al., 2015; Farmer et al., 2015). Atmospheric OA particles consist of hundreds to thousands of organic compounds with a wide range of functionality, solubility, polarity, and volatility and hence pose many challenges and difficulties for characterization of their molecular composition (Hallquist et al., 2009; Noziere et al., 2015; Glasius and Goldstein, 2016). Therefore, there is a critical need for implementation of analytical instrumentation which can be applied to elucidating the composition of OA particles.

Recent advances in the development and application of mass spectrometry (MS) techniques for the analysis of OA particles have been documented in a number of reviews (Noziere et al., 2015; Laskin et al., 2012, 2013; Nizkorodov 
et al., 2011; Pratt and Prather, 2012a, b). Online particle MS techniques that use relatively high-energy vaporization and ionization processes, e.g., flash vaporization of particles followed by electron ionization (DeCarlo et al., 2006; Tobias et al., 2000; Smith et al., 2004) or laser ablation and ionization (Gard et al., 1997; Zelenyuk and Imre, 2005; Murphy and Thomson, 1995), have advantages of high time resolution and real-time quantitative information on composition (DeCarlo et al., 2006; Zhang et al., 2007; Jimenez et al., 2009; $\mathrm{Ng}$ et al., 2010; Murphy and Thomson, 1995; Tobias et al., 2000; Zelenyuk and Imre, 2005; Gard et al., 1997; Pratt and Prather, 2012a, b). However, these techniques typically cause extensive fragmentation of molecules, providing elemental information but limited molecular information on individual organic components.

In contrast, a number of soft-ionization techniques, such as electrospray ionization (ESI), chemical ionization, and photoionization, have been deployed to probe the molecular composition of atmospheric OA particles (Laskin et al., 2012, 2013; Nizkorodov et al., 2011; Pratt and Prather, 2012a, b). Variants of ESI, such as extractive electrospray ionization mass spectrometry (Chen et al., 2006), have recently been applied to the real-time measurement of the molecular composition of OA particles (Doezema et al., 2012; Gallimore and Kalberer, 2013; Horan et al., 2012). In this technique, analyte ionization occurs when the charged solvent spray intersects the sample stream in front of the MS inlet. However, the mechanism for the interaction between charged solvent droplets and samples is not yet well understood (Law et al., 2010; Gallimore and Kalberer, 2013; Jackson et al., 2008; Chen et al., 2006, 2007; Chingin et al., 2008; Wang et al., 2012). In addition, the use of charged solvent sprays may lead to in-source ion clustering of analytes, which is prone to occur in ESI-MS (Gao et al., 2010; Muller et al., 2009b). Chemical ionization mass spectrometry (CIMS) has the advantages of high sensitivity and selectivity as well as high time resolution and has been applied to the online detection of a variety of inorganic and organic gases (Huey, 2007; Noziere et al., 2015). Recently, CIMS employing thermal desorption techniques has been used to measure the molecular composition of OA particles collected onto a substrate (Smith et al., 2004; Winkler et al., 2012; Bzdek et al., 2014; Yatavelli et al., 2012; Lopez-Hilfiker et al., 2014; Aljawhary et al., 2013). As the CIMS technique with a specific reagent ion is highly selective toward certain classes of organic compounds, a comprehensive analysis of the molecular composition of OA particles may require the use of multiple reagent ions. In addition, CIMS is also possibly subject to artifacts from gas-phase ion clustering (Aljawhary et al., 2013).

Direct analysis in real-time mass spectrometry (DARTMS) is an atmospheric-pressure soft-ionization technique allowing for real-time in situ characterization of the molecular composition of gaseous, liquid, and solid samples with a wide range of polarities (Cody et al., 2005; Gross, 2014).
The samples are directly introduced into the ionization region between the MS inlet and the DART ion source, where a heated helium gas flow containing metastable helium atoms $\left(\mathrm{He}^{*}\right)$ generated by a corona discharge is used to thermally volatilize and ionize the sample. Under ambient laboratory conditions, ionization of the analyte occurs primarily through a series of reactions with secondary species, such as protonated water clusters, molecular oxygen ions $\left(\mathrm{O}_{2}^{+}\right)$, and superoxide anions $\left(\mathrm{O}_{2}^{-}\right)$, generated by the reactions between $\mathrm{He}^{*}$ species and atmospheric water and oxygen molecules. The result is the production of mainly $[\mathrm{M}+\mathrm{H}]^{+}, \mathrm{M}^{+}$, and $[\mathrm{M}-\mathrm{H}]^{+}$ions in the positive ion mode and $[\mathrm{M}-\mathrm{H}]^{-}$and $\mathrm{M}^{-}$ ions in the negative ion mode (Cody et al., 2005; Nah et al., 2013; Gross, 2014).

DART-MS has been widely applied to explosive detection, forensic analysis, food analysis, and clinical and pharmaceutical studies (see the review by Gross, 2014, and references therein) as well as to the analysis of OA particles (Chan et al., 2013, 2014; Nah et al., 2013; Davies and Wilson, 2015; Zhou et al., 2015; Schilling Fahnestock et al., 2015; Zhao et al., 2016). It has been previously shown that DART-MS probes several nanometers of the surface layers (Nah et al., 2013; Chan et al., 2013), and this technique has been applied to investigate the bulk and interface regions of particles during reaction (Nah et al., 2013; Chan et al., 2013, 2014; Davies and Wilson, 2015). Zhou et al. (2015) employed DART-MS to study the heterogeneous reactions of $\mathrm{O}_{3}$ with polycyclic aromatic hydrocarbon films coated on the tip of a glass meltingpoint capillary tube. Schilling Fahnestock et al. (2015) recently reported the first application of DART-MS for offline analysis of the composition of SOA from photooxidation of $\mathrm{C}_{12}$ alkanes. In a limited comparison of DART-MS to ESIMS, Zhao et al. (2016) reported that spectra of particles from $\alpha$-cedrene ozonolysis were similar using the two techniques.

In this study, we explore the online application of DARTMS to particles from the reaction of submicron dicarboxylic acid (diacid) particles with gas-phase trimethylamine (TMA) or butylamine (BA) and also report more detailed studies on SOA particles from ozonolysis of the sesquiterpene $\alpha$ cedrene $\left(\mathrm{C}_{15} \mathrm{H}_{24}\right)$. For comparison, measurements by highresolution time-of-flight aerosol mass spectrometry (HRToF-AMS) were also carried out on selected amine-reacted diacid particles. Diacids are among the most abundant components of atmospheric particles, with a dominant source from photochemical and aqueous-phase oxidation processes (Kawamura and Bikkina, 2016; Ervens et al., 2011; Herrmann et al., 2015). Amines, which are ubiquitous in air (Ge et al., 2011), play an important role in particle nucleation and growth (Zhang et al., 2012; Kulmala et al., 2014; Dawson et al., 2012; Chen et al., 2016), formation of light-absorbing OA particles (Laskin et al., 2015; De Haan et al., 2011; Powelson et al., 2014; Duporte et al., 2016), as well as aging of OA particles (Laskin et al., 2015; Müller et al., 2009a). Results from this study provide additional support for the application 


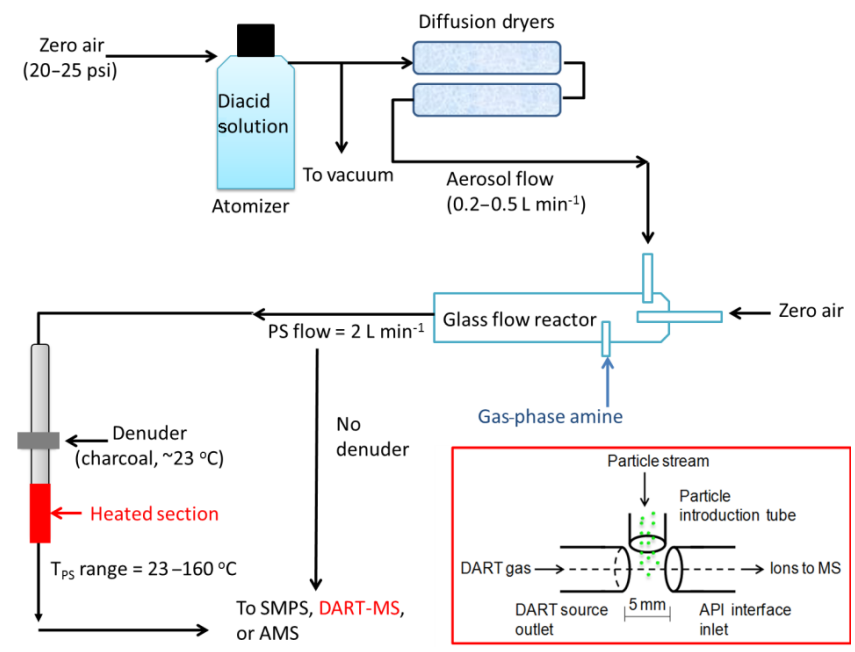

Figure 1. Schematic diagram of the experimental apparatus used for the study of the reaction of diacid particles with gas-phase amines. The inset shows the configuration of the DART ion source interfaced to the MS.

of DART-MS to probe heterogeneous atmospheric reactions and provide additional insights into the nature of organic constituents in complex SOA particles.

\section{Experimental}

\subsection{Generation and reaction of diacid particles with gas-phase amines}

Figure 1 is a schematic diagram of the glass flow reactor (Zhao et al., 2015) used to investigate reactions between gasphase amines (trimethylamine or butylamine) and particles of malonic acid $\left(\mathrm{C}_{3}\right)$, succinic acid $\left(\mathrm{C}_{4}\right)$, glutaric acid $\left(\mathrm{C}_{5}\right)$, adipic acid $\left(\mathrm{C}_{6}\right)$, and pimelic acid $\left(\mathrm{C}_{7}\right)$. Gas-phase trimethylamine (TMA) was generated by passing $1.0 \mathrm{~L} \mathrm{~min}^{-1}$ of clean, dry air (Praxair, ultra zero air) through a U-shaped glass holder containing pure liquid TMA sealed inside a permeation tube (VICI Metronics Inc). Generation of gasphase butylamine (BA) was achieved by injecting an aqueous solution $(1 \% v / v)$, prepared from pure liquid BA (SigmaAldrich, $99.5 \%)$ and nanopure water $(18.2 \mathrm{M} \Omega \mathrm{cm})$, into a flow of $0.5 \mathrm{~L} \mathrm{~min}^{-1}$ of dry air using an automated syringe pump (Pump Systems Inc., model NE-1000) at a rate of $2.4 \mu \mathrm{L} \mathrm{h}^{-1}$. The concentration of TMA in the air flow exiting the permeation tube was measured by collection onto a weak cation exchange resin followed by extraction and analysis using ion chromatography as described previously (Dawson et al., 2014). The initial concentration of TMA in the flow reactor was calculated to be $50 \mathrm{ppb}$ based on the measured concentration from the permeation tube and the dilution factor. The initial concentration of BA, calculated from the amount of the aqueous solution injected and the total air flow in the reactor, was also $50 \mathrm{ppb}$.
For each experiment, the flow reactor was first conditioned overnight with either $1.0 \mathrm{~L} \mathrm{~min}^{-1} \mathrm{TMA}$ or $0.5 \mathrm{~L} \mathrm{~min}^{-1} \mathrm{BA}$ in addition to clean, dry air so that the total flow was $\sim 2 \mathrm{~L} \mathrm{~min}^{-1}$. When the gas-phase concentration of the amine became stable, as indicated by DART-MS signals, a small flow $\left(0.2-0.5 \mathrm{~L} \mathrm{~min}^{-1}\right)$ of air containing dry diacid particles was added to the flow reactor upstream of the amine inlet. The flow of clean, dry air was adjusted to bring the total flow in the reactor to $2.0 \mathrm{~L} \mathrm{~min}^{-1}$, corresponding to a residence time of $44 \mathrm{~s}$. Diacid particles were generated by atomizing aqueous solutions of the corresponding diacid $\left(1 \mathrm{~g} \mathrm{~L}^{-1}\right.$ in nanopure water) using an atomizer (TSI, model 3076) and dried by passing through two diffusion dryers in series (TSI, model 3062). The desiccant inside the dryers was replaced daily to minimize water associated with the particles. The relative humidity $(\mathrm{RH})$ in the flow reactor was $<5 \%$ as measured by a humidity probe (Vaisala, HMT234). All diacids were purchased from Sigma-Aldrich and have a stated purity of $>99 \%$. The size distribution of the particles formed in the flow reactor was measured using a scanning mobility particle sizer (SMPS; TSI) consisting of an electrostatic classifier (model 3080), a long differential mobility analyzer (model 3081), and a condensation particle counter (model $3025 \mathrm{~A}$ or 3776 ). The SMPS was operated with a sheath flow of $3 \mathrm{~L} \mathrm{~min}^{-1}$ and an aerosol flow of $0.3 \mathrm{~L} \mathrm{~min}^{-1}$. Because the flow system required extensive conditioning with the amine prior to introducing the diacid particles, the size distributions represent particles after reaction with amines. Typical surface weighted size distributions are shown in Fig. S1 in the Supplement, and the different weighted geometric mean diameters $\left(\bar{D}_{\mathrm{g}, x}\right.$, where $x=$ number $N$, surface $S$, or volume $V)$ and the total concentrations for all diacid particles are given in Table S1 in the Supplement.

The amine-reacted particle stream (PS) exiting the flow reactor was either directly introduced into the DART ionization region for online measurement of the total (gasphase + particle-bound) amines or passed through a $10 \mathrm{~cm}$ monolith carbon denuder (NovaCarb ${ }^{\mathrm{TM}}$; MAST Carbon, Ltd.) to remove gases and measure only particle-bound amines and diacids. The denuder was maintained at room temperature $\left(T_{\mathrm{PS}}=23^{\circ} \mathrm{C}\right)$. As discussed below, the fraction of particlebound amines was corrected for particle loss in the denuder, which was $\sim 10 \%$ at room temperature (Fig. S1).

\section{$2.2 \alpha$-Cedrene SOA particles generation}

Ozonolysis of $\alpha$-cedrene in the absence of seed particles or $\mathrm{OH}$ scavengers was used to generate SOA particles under dry conditions in the glass flow reactor described previously (Zhao et al., 2016). Gas-phase $\alpha$-cedrene was generated by injecting the pure liquid (Sigma-Aldrich, $>98 \%$ ) into a flow $\left(1.8\right.$ or $\left.3.0 \mathrm{~L} \mathrm{~min}^{-1}\right)$ of clean, dry air using an automated syringe pump. Ozone, produced by passing a flow of $0.24 \mathrm{~L} \mathrm{~min}^{-1}$ of $\mathrm{O}_{2}$ (Praxair, ultra high purity, $99.993 \%$ ) through a Pen-Ray mercury lamp (model 11SC- 
2 ), was added to the flow reactor downstream of the $\alpha$ cedrene inlet. The total gas flow in the reactor was 2.0 or $3.2 \mathrm{~L} \mathrm{~min}^{-1}$, giving a residence time of 44 or $27 \mathrm{~s}$, respectively. The initial $\alpha$-cedrene concentration, calculated from the amount of $\alpha$-cedrene liquid injected into the reactor and the total gas flow, was $138 \mathrm{ppb}$. The initial $\mathrm{O}_{3}$ concentration, measured at the source using a UV-visible spectrometer (Ocean Optics, HR4000), was calculated to be $16 \mathrm{ppm}$ in the reactor after dilution.

Size distributions of SOA particles formed in the flow reactor at the two residence times ( 44 or $27 \mathrm{~s}$ ) were also measured using SMPS (sheath and aerosol flows were 15 and $1.5 \mathrm{~L} \mathrm{~min}^{-1}$, respectively). Typical surface weighted geometric mean diameters $\left(\bar{D}_{\mathrm{g}, \mathrm{S}}\right)$ were measured to be 28 and $21 \mathrm{~nm}$, and number weighted diameters $\left(\bar{D}_{\mathrm{g}, \mathrm{N}}\right)$ were 24 and $16 \mathrm{~nm}$. Once stable, the chemical composition of these particles at both reaction times was measured online using DART-MS. Before entering into the DART ionization region, $2.0 \mathrm{~L} \mathrm{~min}^{-1}$ of particle stream exiting the reactor was first passed through a $10 \mathrm{~cm}$ monolith carbon denuder to remove the gas-phase species and then heated to different temperatures (up to $T_{\mathrm{PS}}=160^{\circ} \mathrm{C}$ ) in a stainless steel tube wrapped with a heating tape. The residence time of the particle stream in the heated tube was $\sim 4 \mathrm{~s}$. Although the use of the denuder caused a $\sim 30 \%$ loss of SOA particles at room temperature, it had no significant influence on the size distribution, for which a typical example is shown in Fig. S2.

\subsection{DART-MS measurement operating conditions}

The chemical composition of either amine-reacted diacid particles or $\alpha$-cedrene SOA particles was measured online using a triple quadrupole mass spectrometer (Waters, Xevo TQ-S) equipped with a commercial DART ion source (IonSense, DART SVP with Vapur ${ }^{\circledR}$ Interface). The DART probe was placed at the entrance of the MS, with a distance of $5 \mathrm{~mm}$ and a relative angle of $180^{\circ}$ (Fig. 1), and was operated under the following conditions: He reagent gas flow $3.1 \mathrm{~L} \mathrm{~min}^{-1}$; $\mathrm{He}$ gas temperature $350^{\circ} \mathrm{C}$ (which gives a measured temperature of $\sim 260^{\circ} \mathrm{C}$ in the ionization region with or without the particle; Fig. S3); grid electrode voltage 350 V. Mass spectra were collected in the range $m / z 20-500$ for the amine-diacid particle systems and $m / z$ 100-1000 for $\alpha$-cedrene SOA particles. Each spectrum was acquired by averaging the signal over 2-4 min of sampling time. Background spectra were also recorded by measuring a clean air stream under conditions identical to those for online particle stream measurements and subtracted from particle spectra.

\subsection{DART-MS analysis of amine-reacted diacid particles}

For the amine-diacid particle systems, both the gas-phase and particle-bound amines were detected as $[\mathrm{M}+\mathrm{H}]^{+}$ions in the positive ion mode and the diacids as $[\mathrm{M}-\mathrm{H}]^{-}$in the negative ion mode. Amine-diacid clusters were not observed in the mass spectra (Fig. S4). As described earlier, the particlebound and the total (gas-phase + particle-bound) amines can be measured in the presence and absence of a denuder, respectively. Thus, assuming the same ionization efficiency for the gas-phase and particle-phase amines, the fraction of amine taken up by the particles $\left(f_{\mathrm{p}}\right)$ can be derived from Eq. (1).

$f_{\mathrm{p}}=\frac{\text { amine ion signal measured with denuder } \times C_{\mathrm{f}}}{\text { amine ion signal measured without denuder }}$,

where $C_{\mathrm{f}}$ is the correction factor for the particle loss in the denuder and has a value of 1.1 (Sect. S1 in the Supplement). The value of $f_{\mathrm{p}}$ can be an indicator of the reactivity of diacid particles toward amines. Given the difference in surface area concentrations of different diacid particles (Table S1), the measured $f_{\mathrm{p}}$ was normalized to an arbitrary reference surface area of $1 \times 10^{-4} \mathrm{~cm}^{2} \mathrm{~cm}^{-3}$ for direct comparisons of the reactivity of different amine-diacid systems. Thus, the particle-phase fraction of amine taken up by the diacid normalized by surface area, $\left(F_{\mathrm{p}}\right)$, is given by

$F_{\mathrm{p}}=\frac{f_{\mathrm{p}}}{\frac{\text { aerosol surface area concentration }\left(\mathrm{cm}^{2} \mathrm{~cm}^{-3}\right)}{\text { reference surface area }\left(\mathrm{cm}^{2} \mathrm{~cm}^{-3}\right)}}$.

The molar ratio $\left(R_{\mathrm{B} / \mathrm{A}}\right)$ of amine (base, $\left.\mathrm{B}\right)$ to diacid $(\mathrm{A})$ in amine-reacted diacid particles can also provide important insights into the reactivity of the diacid particles toward amines. Values of $R_{\mathrm{B} / \mathrm{A}}$ were derived first for four aqueous standard solutions with different amine concentrations (0.5$10 \mathrm{mM}$ ) but constant diacid concentrations $(10 \mathrm{mM})$ for each amine-diacid system. As shown below, this covers the range measured for the reacted particles. A melting-point capillary tube was dipped into the standard solution and immediately placed into the DART ionization region for analysis. A linear relationship between the base-to-diacid molar ratio $\left(R_{\mathrm{B} / \mathrm{A}}\right)$ of the aqueous solutions and the corresponding DART-MS signal ratios for amine $\left([\mathrm{M}+\mathrm{H}]^{+}\right)$to diacid $\left([\mathrm{M}-\mathrm{H}]^{-}\right)$was observed for each standard solution (Fig. S5). These relationships were then used to estimate the $R_{\mathrm{B} / \mathrm{A}}$ value in aminereacted diacid particles.

\subsection{DART-MS analysis of $\alpha$-cedrene SOA particles}

$\alpha$-Cedrene SOA particles were analyzed in the negative ion mode, where the deprotonated $[\mathrm{M}-\mathrm{H}]^{-}$ions dominate. In other studies, DART-MS was proposed to preferentially 


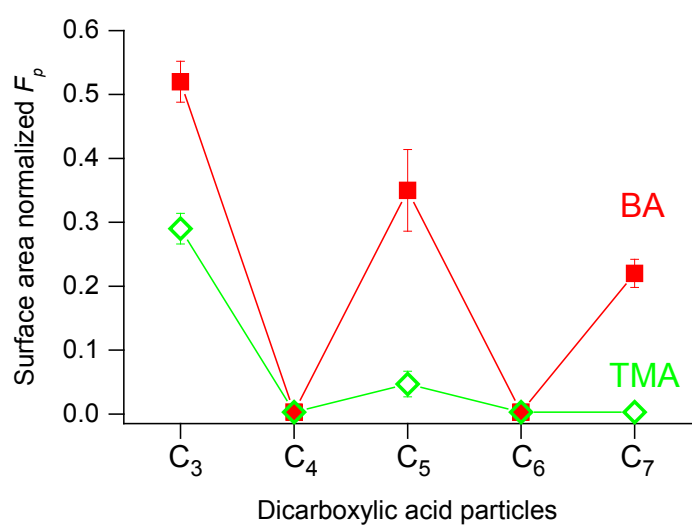

Figure 2. Surface area normalized fraction $\left(F_{\mathrm{p}}\right)$ of butylamine (solid square) and trimethylamine (open diamond) in amine-reacted $\mathrm{C}_{3}-\mathrm{C}_{7}$ dicarboxylic acid particles measured at $T_{\mathrm{PS}}=23^{\circ} \mathrm{C}$. Error bars are $\pm 1 \sigma$.

probe the surface layers of particles, and the measured ion signal was sensitive to the volatility of the analytes (Nah et al., 2013; Chan et al., 2013). In the present studies, the gasphase species were removed by a denuder, and the particle stream was then exposed to temperatures up to $160^{\circ} \mathrm{C}$ prior to introduction into the DART ionization region, in order to probe the bulk of the particles and low-volatility components of SOA particles such as high molecular weight (HMW) products.

\subsection{HR-TOF-AMS measurements}

In some experiments, the chemical composition of TMAreacted diacid particles was also analyzed online using an Aerodyne high-resolution aerosol mass spectrometer (HRToF-AMS). Analysis of HR-ToF-AMS high-resolution mass spectra was carried out using SQUIRREL V1.56D-1.57I and PIKA V1.15D-1.61I analysis software with IGOR Pro (Wavemetrics, Inc.). Default values for the fragmentation tables were used, except for corrections to the isotopic abundance of ${ }^{15} \mathrm{~N}^{14} \mathrm{~N}$, which is not resolved from $\mathrm{CHO}^{+}$at $m / z, 29$ and was quantified for each experiment with the use of a particle filter (Canagaratna et al., 2015). Default relative ionization efficiency values were used for all organics, while those for TMA were measured as discussed in the Supplement (Sect. S5). TMA-reacted diacid particles, with and without a denuder, gave similar results and were averaged to generate mass spectra for each TMA-diacid system (Fig. S6). From these mass spectra, the ratio of $\mathrm{C}_{x} \mathrm{H}_{y} \mathrm{~N}_{1}^{+}$fragments to the sum of $\mathrm{C}_{x} \mathrm{H}_{y}^{+}$and $\mathrm{C}_{x} \mathrm{H}_{y} \mathrm{O}_{z}^{+}$fragments, which is a measure of the ratio of amine to diacid, was determined for each TMA-diacid system (Fig. S7). Because these particles are efficiently vaporized at the vaporizer temperature employed $\left(T_{\text {vap }}=600^{\circ} \mathrm{C}\right)$, the amine to diacid ratios from HR-ToFAMS measurements reflect the overall composition of the particle ensemble.

\section{Results and discussion}

\subsection{Reaction of diacid particles with gas-phase amines}

\subsubsection{DART-MS data}

Figure 2 shows the surface area normalized fraction $\left(F_{\mathrm{p}}\right)$ of BA or TMA in the particle phase of amine-reacted $\mathrm{C}_{3}-\mathrm{C}_{7}$ diacid particles as a function of carbon number. The oddcarbon diacids take up much more base than the even-carbon diacids, with no particle-bound amines detected for the $\mathrm{C}_{4}$ and $\mathrm{C}_{6}$ diacids. The measured $F_{\mathrm{p}}$ values for both amines decrease with increasing carbon number, with no particlebound TMA observed for pimelic acid $\left(\mathrm{C}_{7}\right)$. An odd-even alternation in physical properties, such as melting point (Thalladi et al., 2000), vapor pressure (Bilde et al., 2003, 2015; Cappa et al., 2007; Bruns et al., 2012), and solubility (Zhang et al., 2013), is well known for diacids. Some studies have probed a possible odd-even alternation in their reactivity with $\mathrm{HO}_{2}$ (Taketani et al., 2013), $\mathrm{NO}_{3}$ (de Semainville et al., 2010), and $\mathrm{N}_{2} \mathrm{O}_{5}$ (Griffiths et al., 2009), as well as in their $\mathrm{TiO}_{2}$-based photocatalytic degradation (Sun et al., 2014). Recent studies of the uptake of amines on diacids also show an odd-even effect (Fairhurst et al. 2017).

The alternating behaviors between odd and even diacids have generally been attributed to the differences in their crystal structures. For example, odd-carbon diacids have a higher aqueous solubility than even-carbon diacids because of the energetically unfavorable and looser crystal packing for the former, which facilitates the penetration of water molecules between the molecular planes to dissolve the crystal (Zhang et al., 2013). It is possible that small amines, like water molecules, can also disrupt the crystal lattice of odd-carbon diacids more readily than that of the even-carbon species, thus leading to the observed odd-even alternation in the chemical reactivity. This may also explain why uptake of TMA is significantly smaller than BA (Fig. 2), where the bulky TMA structure may hinder the penetration and disruption of the diacid crystal lattice. A similar steric effect has also been reported by Liu et al. (2012) to explain the trends in reactivity on citric acid and humic acid particles of methylamine, dimethylamine, and TMA, which decreases with an increasing number of methyl groups.

Alternatively, the odd-even differences could be due to differences in surface composition and structure. Ruehl and Wilson (2014) observed an odd-even alternation in the hygroscopic growth of aqueous ammonium sulfate particles with a diacid shell. They attributed this behavior to the differences in the surface orientation of odd and even diacids on aqueous droplets, i.e., the "end-to-end" alignment with only one carboxyl group in contact with the aqueous phase for odd-carbon diacids versus the "folded" arrangement with both carboxyl groups in contact with the aqueous phase for the even-carbon diacids. If a similar effect is present in the solids, an odd-even alternation in the reactivity with amines 
Table 1. $R_{\mathrm{B} / \mathrm{A}}$ values for amine-reacted malonic acid $\left(\mathrm{C}_{3}\right)$, glutaric acid $\left(\mathrm{C}_{5}\right)$, and pimelic acid $\left(\mathrm{C}_{7}\right)$ particles derived by DART-MS, HR-ToF-AMS, and calculations.

\begin{tabular}{lrrr}
\hline & $\begin{array}{r}R_{\mathrm{B} / \mathrm{A}} \\
\text { (DART-MS) }\end{array}$ & $\begin{array}{r}R_{\mathrm{B} / \mathrm{A}} \\
\text { (AMS) }\end{array}$ & $\begin{array}{r}\text { Calculated } R_{\mathrm{B} / \mathrm{A} \text { from }} \\
F_{\mathrm{p}} \text { and the particle } \\
\text { size distributions }\end{array}$ \\
\hline TMA-C $_{3}$ & $0.28 \pm 0.07$ & $0.14 \pm 0.01$ & $0.07 \pm 0.02$ \\
TMA-C $_{5}$ & $0.05 \pm 0.02$ & $0.03 \pm 0.01$ & $0.02 \pm 0.003$ \\
TMA-C $_{7}$ & $\mathrm{a}$ & $0.01 \pm 0.001$ & $\mathrm{a}$ \\
BA-C $_{3}$ & $0.40 \pm 0.09$ & $\mathrm{~b}$ & $0.09 \pm 0.03$ \\
BA-C $_{5}$ & $0.22 \pm 0.02$ & $\mathrm{~b}$ & $0.07 \pm 0.01$ \\
BA-C $_{7}$ & $0.42 \pm 0.06$ & $\mathrm{~b}$ & $0.07 \pm 0.02$ \\
\hline
\end{tabular}

${ }^{\mathrm{a}}$ No particle-bound amines were detected by DART-MS. ${ }^{\mathrm{b}}$ Measurements by AMS were not performed. ${ }^{\mathrm{c}}$ See Eqs. (3) and (4) in text. Lower limit due to uncertainty in particle density is as described in the text.

could result due to differences in surface availability of the $-\mathrm{COOH}$ groups.

Based on previous work by Lavi et al. (2015) the diacid and their alkylaminium salts vaporize well below $100^{\circ} \mathrm{C}$. Thus, in some experiments, the amine-reacted diacid particles were heated after exiting the $10 \mathrm{~cm}$ monolith denuder and prior to entering the DART-MS ionization region to probe whether the amine was distributed throughout the bulk of the particle or segregated on the surface. As seen in Fig. 3, there is no obvious temperature dependence for $F_{\mathrm{p}}$ values, indicating that all of the amines in the particles are being sampled under all conditions. One explanation is that the entire particle is being sampled. Alternatively, if the amine reactions are restricted to a surface layer as is common for gas-solid interactions, then the surface layer being probed at all $T_{\mathrm{PS}}$ is sufficiently deep to detect the entire particle-bound base. We show in the following that the latter is the likely explanation.

The molar ratio of amine to diacid $\left(R_{\mathrm{B} / \mathrm{A}}\right)$ in aminereacted diacid particles was estimated by comparing the DART-MS signal intensity ratio of amine to diacid measured at $T_{\mathrm{PS}}=23^{\circ} \mathrm{C}$ with that for known amine-diacid standard solutions (Fig. S5). As listed in Table 1, the $R_{\mathrm{B} / \mathrm{A}}$ values follow a similar trend to $F_{\mathrm{p}}$ (Fig. 2) for TMA- and BA-reacted malonic acid $\left(\mathrm{C}_{3}\right)$ and glutaric acid $\left(\mathrm{C}_{5}\right)$ particles.

However, the value of $R_{\mathrm{B} / \mathrm{A}}$ for BA-reacted pimelic acid $\left(\mathrm{C}_{7}\right)$ particles is larger than that for BA-reacted glutaric acid and malonic acid, inconsistent with the trend in $F_{\mathrm{p}}$. A possible explanation can be suggested based on differences in the saturation vapor pressures $\left(P_{\text {sat }}\right.$; Bilde et al., 2015) of these diacids. It has been shown that the probe depth of online DART-MS is positively correlated with the volatility of straight-chain even-diacid particles (Chan et al., 2013). Given that the volatility of $\mathrm{C}_{7}\left(P_{\text {sat }}=1.1 \times 10^{-10} \mathrm{~atm}\right)$ is substantially lower than that of both $\mathrm{C}_{3}$ and $\mathrm{C}_{5}$, which are $\sim 1.7 \times 10^{-9} \mathrm{~atm}$, the probe depth for $\mathrm{C}_{7}$ particles is expected to be significantly smaller than the other two diacid particles, i.e., about a factor of 8 if the probe depth-volatility
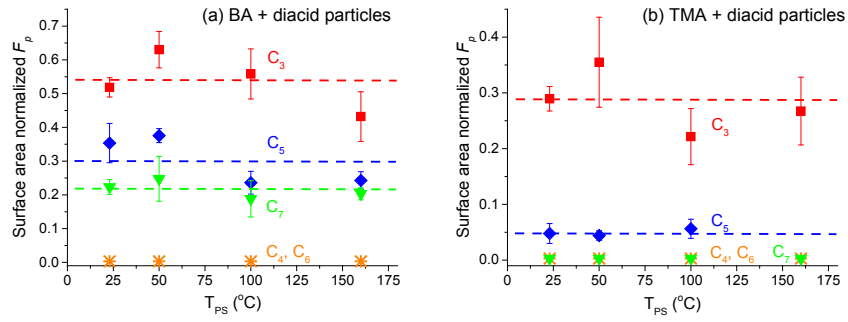

Figure 3. Surface area normalized fraction $\left(F_{\mathrm{p}}\right)$ of (a) butylamine and (b) trimethylamine in amine-reacted $\mathrm{C}_{3}-\mathrm{C}_{7}$ diacid particles measured at different particle stream heating temperatures $\left(T_{\mathrm{PS}}\right)$. The dashed line represents the average of $F_{\mathrm{p}}$ values at different $T_{\mathrm{PS}}$. Error bars are $\pm 1 \sigma$.

relationship reported for the even-diacid particles is extrapolated to the odd diacids (Fig. S8). Correcting for this, the $R_{\mathrm{B} / \mathrm{A}}$ value would be about a factor of 8 smaller, i.e., $\sim 0.05$, which would follow the trend for the $F_{\mathrm{p}}$ values for all three amine-reacted odd-diacid particles. Note that although the probe depth may be smaller for $\mathrm{C}_{7}$, the $F_{\mathrm{p}}$ value (Fig. 2) for the BA reaction suggests that it is still sufficient to detect all of the particle-bound amine (Fig. 3).

\subsubsection{Comparison with HR-ToF-AMS data}

The $R_{\mathrm{B} / \mathrm{A}}$ values for TMA-reacted $\mathrm{C}_{3}$ and $\mathrm{C}_{5}$ diacid particles were also measured using HR-ToF-AMS and are shown in Table 1 and Fig. S7. The $R_{\mathrm{B} / \mathrm{A}}$ values for malonic acid and glutaric acid particles measured by HR-ToF-AMS are smaller than the corresponding values determined by DARTMS. The interaction between amines and carboxylic acids forms aminium carboxylate salts (Liu et al., 2012; Angelino et al., 2001; Lavi et al., 2015; Gomez-Hernandez et al., 2016), so the gas-solid reaction is expected to form a surface layer of the salt. However, HR-ToF-AMS measures the entire particle (i.e., both the surface reacted layer and the unreacted bulk). The larger $R_{\mathrm{B} / \mathrm{A}}$ values from DART-MS show that it is probing the reacted surface layer containing the aminium salt plus, perhaps, some fraction of the underlying diacid. This is consistent with other studies where DART-MS was shown to probe mainly the surface layer (Chan et al., 2013; Nah et al., 2013).

In addition to direct measurements by HR-ToF-AMS, the $R_{\mathrm{B} / \mathrm{A}}$ values for the entire amine-reacted diacid particles can also be estimated by combining DART-MS with SMPS data. The number of amine molecules in the particles per $\mathrm{cm}^{3}$ of air ( $N_{\text {p-amine }}$, molecules $\mathrm{cm}^{-3}$ air; Table S2) can be derived from Eq. (3).

$N_{\text {p-amine }}=F_{\mathrm{p}} \times N_{\text {total }}$,

where $F_{\mathrm{p}}$ is as defined in Eq. (2) and $N_{\text {total }}$ is the amount of amines in the gas phase plus those bound to the particles (molecules $\mathrm{cm}^{-3}$ air) estimated from the DART-MS signal 
for the total amines and the DART-MS sensitivity to amines calibrated using gas-phase amines with known concentrations, generated as described in the experimental section. The number of diacid molecules in the particles per $\mathrm{cm}^{3}$ air $\left(N_{\text {p-acid }}\right)$ can be estimated from Eq. (4).

$N_{\text {p-acid }}=\frac{\left[\left(V_{\mathrm{p}} \times \rho\right)-m_{\mathrm{p} \text {-amine }}\right] \times N_{A}}{\mathrm{MW}_{\mathrm{acid}}}$,

where $V_{\mathrm{p}}$ is the total volume concentration of amine-reacted diacid particles measured by SMPS $\left(\mathrm{cm}^{3}\right.$ particle volume $\mathrm{cm}^{-3}$ air); $\rho$ is the density of amine-reacted diacid particles, which is assumed to be the same as the solid diacid samples (i.e., $1.619 \mathrm{~g} \mathrm{~cm}^{-3}$ for malonic acid, $1.429 \mathrm{~g} \mathrm{~cm}^{-3}$ for glutaric acid, and $1.329 \mathrm{~g} \mathrm{~cm}^{-3}$ for pimelic acid; Lide, 2004); $m_{\text {p-amine }}$ is the mass concentration of particle-phase amines $\left(\mathrm{g} \mathrm{cm}^{-3}\right.$ air), which can be determined from Eq. (3); $\mathrm{MW}_{\text {acid }}$ is the molecular weight of the corresponding diacid ( $\mathrm{g} \mathrm{mol}^{-1}$ ); and $N_{A}$ is Avogadro's number.

The $R_{\mathrm{B} / \mathrm{A}}$ values calculated from the ratio of $N_{\mathrm{p} \text {-amine }}$ to $N_{\text {p-acid }}$ are presented in Table 1 . They are significantly smaller than those directly determined by DART-MS, further confirming that DART-MS mainly probes the surface layer of particles and that the amines are segregated at the surface.

However, the calculated values are also smaller than the values measured by HR-ToF-AMS. This is likely because the densities of the pure diacids were used in the calculations. Salts formed by reaction of amines with diacids tend to have densities that are smaller by as much as $\sim 30 \%$ (Lavi et al., 2015). Small decreases in particle density would decrease the calculated particle mass concentrations and $n_{\text {p-acid }}$ (Eq. 4) and, hence, increase the calculated $R_{\mathrm{B} / \mathrm{A}}$ values. Despite the difference in the absolute values of $R_{\mathrm{B}} / \mathrm{A}$, the trends in $R_{\mathrm{B} / \mathrm{A}}$ values for TMA-reacted malonic acid and glutaric acid particles, derived by DART-MS, HR-ToF-AMS, and calculations, are consistent within the experimental uncertainty.

\subsubsection{Estimation of probe depth for TMA-reacted odd-diacid particles}

When an amine reacts with a diacid, the resulting particle with radius $R$ is assumed to contain a diacid core $\left(r_{1}\right)$ and an aminium salt shell of thickness $L_{\text {shell }}=\left(R-r_{1}\right)$, as shown in Fig. 4. The total volume of the particle, assuming a spherical geometry, can be expressed as

$V_{\text {total }}=\frac{4}{3} \pi R^{3}$.

$V_{\text {total }}$ can be obtained directly from SMPS data (Table S1). Since the total particle is comprised of the acid core and aminium salt shell, the total volume can also be expressed as

$V_{\text {total }}=V_{\mathrm{s}}+V_{\mathrm{c}}$,

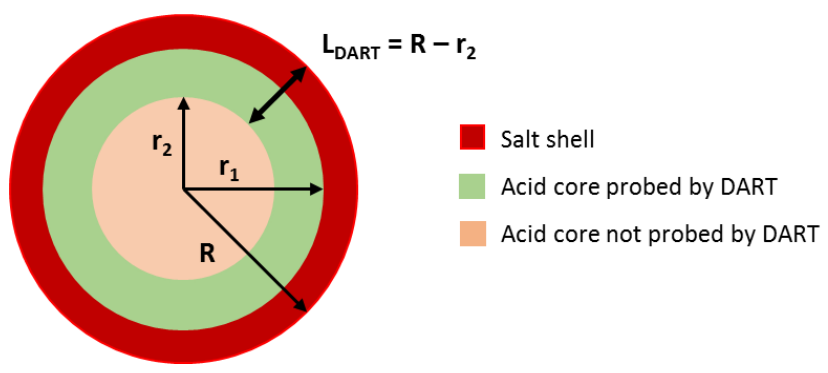

Figure 4. Schematic of a typical amine-reacted diacid particle as probed by DART-MS.

where $V_{\mathrm{c}}$ is the volume of the acid core and $V_{\mathrm{s}}$ is the volume of the aminium salt shell. The volume of the shell can be obtained from the experimental data as follows:

$V_{\mathrm{s}}=\frac{m_{\mathrm{s}}}{\rho_{\mathrm{s}}}=\frac{n_{\mathrm{s}} \mathrm{MW}_{\mathrm{s}}}{\rho_{\mathrm{s}}}$.

In Eq. (7), $m_{\mathrm{s}}$ is the mass of the aminium salt, $\rho_{\mathrm{s}}$ is the density of the salt, $n_{\mathrm{s}}$ is the number of moles of salt per $\mathrm{cm}^{3}$ air, and $\mathrm{MW}_{\mathrm{s}}$ is the molecular weight of the aminium salt. Note that two values of $V_{\mathrm{s}}$ can be calculated if aminium salt forms with stoichiometric molar amine : acid ratios of either $1: 1$ or $2: 1$. In addition, the densities of the aminium salts are reported to be less than that of the pure acid, as much as $\sim 30 \%$ lower for the $2: 1$ salt (Lavi et al., 2015). For the calculations below, the density of the salt is taken to be either $15 \%$ smaller than the acid for a $1: 1$ base-to-acid salt or $30 \%$ smaller for the $2: 1$ salt.

Thus, one can solve for $r_{1}$ as follows:

$\frac{R}{r_{1}}=\left(\frac{V_{\text {total }}}{V_{\text {core }}}\right)^{\frac{1}{3}}=\left(\frac{V_{\text {total }}}{V_{\text {total }}-V_{\mathrm{s}}}\right)^{\frac{1}{3}}$.

Using the volume-weighted geometric-mean diameter (nm; Table S1) in Eq. (8) to obtain $R$, the radius of the acid core, $r_{1}$, as well as the thickness of the salt layer, $L_{\text {shell }}\left(L_{\text {shell }}=\right.$ $R-r_{1}$ ), can be obtained. Table 2 summarizes the results for TMA-reacted malonic acid and glutaric acid particles.

The probe depth $\left(L_{\mathrm{DART}}\right)$ is assumed to be comprised of the aminium salt shell (shaded red area; Fig. 4) and some fraction of the acid core (shaded green area). The thickness of the aminium salt layer, determined previously $\left(L_{\text {shell }}\right)$, along with the ratio of $R_{\mathrm{B} / \mathrm{A}}$ values for a given diacid, derived by DART-MS and HR-ToF-AMS (Table 1), can be used to estimate the probe depth of the reacted particles in the following manner.

As discussed earlier, the independence of $F_{\mathrm{p}}$ on particle stream temperature $\left(T_{\mathrm{ps}}\right.$; Fig. 3$)$ suggests that DART-MS probes all of the aminium salt shell plus likely some of the pure acid core. In contrast, because HR-ToF-AMS measures the entire particle, it probes the total amount of the amine present in the particles and all of the pure acid core (by measuring the entire particles). Thus, the ratio of the $R_{\mathrm{B} / \mathrm{A}}$ val- 
Table 2. Thickness of the aminium salt shell and DART probe depth for trimethylamine (TMA)-reacted malonic acid and glutaric acid* .

\begin{tabular}{lrrrrrrrrr}
\hline & $R(\mathrm{~nm})$ & \multicolumn{2}{c}{$r_{1}(\mathrm{~nm})$} & \multicolumn{2}{c}{$r_{2}(\mathrm{~nm})$} & \multicolumn{2}{c}{$L_{\text {shell }}(\mathrm{nm})$} & \multicolumn{2}{c}{$L_{\text {DART }}(\mathrm{nm})$} \\
\cline { 2 - 10 } & & $1: 1$ & $2: 1$ & $1: 1$ & $2: 1$ & $1: 1$ & $2: 1$ & $1: 1$ & $2: 1$ \\
\hline Malonic acid & 145 & 139 & 140 & 113 & 113 & 5.5 & 4.5 & 32 & 32 \\
Glutaric acid & 135 & 133 & 133 & 106 & 106 & 1.7 & 1.4 & 28 & 28 \\
\hline
\end{tabular}

* $1: 1$ means a molar ratio of one amine to one diacid. $2: 1$ means two moles of amine to one mole of diacid.

ues from DART-MS to that of the HR-ToF-AMS can be expressed as

$$
\frac{R_{\mathrm{B} / \mathrm{A}, \mathrm{DART}}}{R_{\mathrm{B} / \mathrm{A}, \mathrm{AMS}}}=\frac{\frac{\text { moles } \mathrm{B}(\mathrm{DART})}{\text { moles } \mathrm{A}(\mathrm{DART})}}{\frac{\text { moles } \mathrm{B}(\mathrm{AMS})}{\text { moles } \mathrm{A}(\mathrm{AMS})}}=\frac{\text { moles } \mathrm{A}(\mathrm{AMS})}{\text { moles } \mathrm{A}(\mathrm{DART})} .
$$

The total volume of a particle can be expressed as a function of the different areas labeled in Fig. 4 as

$$
V_{\mathrm{total}}=V_{\mathrm{s}}+V_{\mathrm{m}}+V_{\mathrm{uc}}
$$

where $V_{\mathrm{s}}, V_{\mathrm{m}}$, and $V_{\mathrm{uc}}$ are the volume of the salt shell (shaded red area), the volume of the middle layer (i.e., the volume of the acid core that is probed by DART-MS, shaded green area), and the volume of the core that is not probed by DART (yellow area), respectively. While DART-MS is assumed to probe the salt layer and some fraction of the acid core, the HR-ToF-AMS probes the entire bulk of the particle. As a result, Eq. (9) can be expressed as follows,

$$
\frac{R_{\mathrm{B} / \mathrm{A}, \mathrm{DART}}}{R_{\mathrm{B} / \mathrm{A}, \mathrm{AMS}}}=\frac{\frac{\rho_{\mathrm{s}} V_{\mathrm{s}}}{\mathrm{MW}_{\mathrm{s}}}+\frac{\rho_{\mathrm{A}} V_{\mathrm{m}}}{\mathrm{MW}_{\mathrm{A}}}+\frac{\rho_{\mathrm{A}} V_{\mathrm{uc}}}{\mathrm{MW}_{\mathrm{A}}}}{\frac{\rho_{\mathrm{s}} V_{\mathrm{s}}}{\mathrm{MW}_{\mathrm{s}}}+\frac{\rho_{\mathrm{A}} V_{\mathrm{m}}}{\mathrm{MW}_{\mathrm{A}}}},
$$

where $\rho_{\mathrm{S}}$ and $\mathrm{MW}_{\mathrm{s}}$ are the density and molecular weight for the aminium salt and $\rho_{\mathrm{A}}$ and $\mathrm{MW}_{\mathrm{A}}$ are the density and molecular weight of the diacid contained in the "middle" layer and the acid core that is not probed by DART-MS.

The ratio of the base-to-acid molar ratio from DARTMS to that of the HR-ToF-AMS is $\sim 2$ (Table 1). As such, Eq. (11) can be simplified to yield Eq. (12):

$$
\frac{\rho_{\mathrm{s}} V_{\mathrm{s}}}{\mathrm{MW}_{\mathrm{s}}}+\frac{\rho_{\mathrm{A}} V_{\mathrm{m}}}{\mathrm{MW}_{\mathrm{A}}}=\frac{\rho_{\mathrm{A}} V_{\mathrm{uc}}}{\mathrm{MW}_{\mathrm{A}}}
$$

The spherical volumes of each section of the particle can now be expressed in terms of their respective radii based on Fig. 4:

$$
\frac{\rho_{\mathrm{s}}\left(R^{3}-r_{1}^{3}\right)}{\mathrm{MW}_{\mathrm{s}}}+\frac{\rho_{\mathrm{A}}\left(r_{1}^{3}-r_{2}^{3}\right)}{\mathrm{MW}_{\mathrm{A}}}=\frac{\rho_{\mathrm{A}} r_{2}^{3}}{\mathrm{MW}_{\mathrm{A}}}
$$

The values of $r_{2}$ corresponding to a stoichiometric molar amine : acid ratio of $1: 1$ or $2: 1$ can then be derived along with the derived probe depth for DART-MS, $L_{\mathrm{DART}}=(R-$ $\left.r_{2}\right)$. As can be seen in Table 2, using the volume-weighted geometric-mean diameter for the TMA-reacted malonic acid of $290 \mathrm{~nm}$ (Table S1), the decrease in the DART-MS ratio of

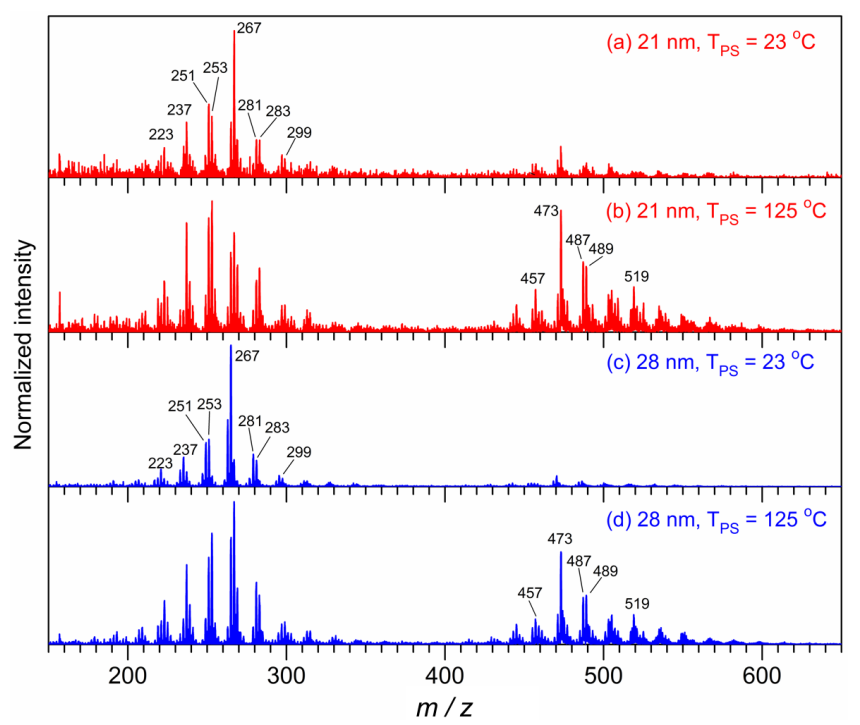

Figure 5. DART(-) mass spectra of polydisperse $\alpha$-cedrene SOA particles with surface weighted geometric mean diameters $\left(\bar{D}_{\mathrm{g}, \mathrm{S}}\right)$ of $21 \mathrm{~nm}(\mathbf{a}, \mathbf{b})$ and $28 \mathrm{~nm}(\mathbf{c}, \mathbf{d})$ at $T_{\mathrm{PS}}=23$ and $125^{\circ} \mathrm{C}$. $T_{\mathrm{PS}}$ denotes the particle stream temperature before introduction into the DART ionization region.

$R_{\mathrm{B} / \mathrm{A}}$ from 0.28 to 0.14 for HR-ToF-AMS is consistent with a probe depth of $\sim 32 \mathrm{~nm}$ and is similar for glutaric acid, $\sim 28 \mathrm{~nm}$. It is worth noting that the values obtained for $r_{2}$ and $L_{\text {DART }}$ are essentially independent of the assumed stoichiometry and would yield the same value for any mixture of $1: 1$ and $2: 1$ salt.

\subsection{Characterization of $\alpha$-cedrene SOA particles}

In earlier studies (Zhao et al., 2016), limited DART-MS measurements were made for SOA particles at $T_{\mathrm{PS}}=160^{\circ} \mathrm{C}$ from the ozonolysis of $\alpha$-cedrene for the purposes of confirming high molecular weight products identified in ESI mass spectra. More extensive measurements were carried out here to investigate, in more detail, the application of DARTMS to organic particles of complex composition. Figure 5 shows DART(-) mass spectra of polydisperse $\alpha$-cedrene SOA particles measured as a function of $T_{\mathrm{PS}}$ for distributions with different $\bar{D}_{\mathrm{g}, \mathrm{S}}$, i.e., 21 and $28 \mathrm{~nm}$. The ion signals observed in the mass spectra of SOA particles at $T_{\mathrm{PS}}=23^{\circ} \mathrm{C}$ 
(Fig. 5a and c) are dominated by low molecular weight (LMW) products $(m / z 200-350)$, with a small contribution from HMW products $(m / z 420-580)$. This is not surprising given the very short particle residence time in the ionization region (estimated to be of the order of milliseconds under our conditions), which limits the vaporization of lowvolatility HMW products from SOA particles. However, the signal intensities of the HMW products as well as most of the LMW products increase substantially at $T_{\mathrm{PS}}=125^{\circ} \mathrm{C}$ (Fig. $5 b$ and d). It is not known whether the entire particle is vaporized at this temperature, although essentially complete vaporization has been reported for larger SOA particle diameters (Kolesar et al., 2015). Many of the LMW products in $\alpha$ cedrene SOA particles observed in DART mass spectra were also detected using gas chromatography-mass spectrometry (Jaoui et al., 2004, 2013; Yao et al., 2014) and atmospheric pressure chemical ionization-mass spectrometry (Reinnig et al., 2009) in other studies. The possible structures and formation mechanism of many of these LMW products were investigated in other studies (Jaoui et al., 2004, 2013; Reinnig et al., 2009; Yao et al., 2014; Zhao et al., 2016) and those for HMW products in our previous study (Zhao et al., 2016).

Potential artifacts in DART-MS, with respect to in-source oxidation chemistry and gas-phase ion clustering of organic compounds that form non-covalently bound HMW species, were evaluated by analyzing different organic standards and $\alpha$-cedrene SOA particles in the negative ion mode under varying controlled conditions. Details of the analysis and results can be found in Sect. S8. The results show that measurements of diacid particles and $\alpha$-cedrene SOA particles with DART-MS do not suffer from in-source oxidation and gas-phase-clustering artifacts.

The differences in DART mass spectra of $\alpha$-cedrene SOA particles at $T_{\mathrm{PS}}=23$ or $125^{\circ} \mathrm{C}$ in Fig. 5 are consistent with a dependence of product distribution on particle size, as reported earlier based on ESI-MS (Zhao et al., 2016). To better explore the size- and temperature-dependent product distribution in $\alpha$-cedrene SOA particles, the intensity ratio of HMW to LMW products as well as the intensity fraction of the two prominent LMW products, i.e., $m / z 253$ and $m / z 267$, was examined as a function of $T_{\mathrm{PS}}$ and particle size. Figure 6a shows the signal intensity ratio of HMW products (summed over $m / z 420-580$ ) to that of LMW products (summed over $m / z$ 200-350) for $\alpha$-cedrene SOA particles with a $\bar{D}_{\mathrm{g}, \mathrm{S}}$ of 21 and $28 \mathrm{~nm}$ at different $T_{\mathrm{PS}}$. Smaller particles at each $T_{\mathrm{PS}}$ show a greater contribution from HMW products to the total ion signal, consistent with these products serving as important agents for initial particle formation (Zhao et al., 2016).

In our previous study (Zhao et al., 2016), HR-ToF-AMS was used to characterize the bulk composition of $\alpha$-cedrene ozonolysis particles generated in Teflon chambers. Under dry conditions $(<5 \% \mathrm{RH})$, chamber-generated particles had an $\mathrm{O}: \mathrm{C}=0.34$, which was characteristic of LMW products that were shown to contribute primarily to particle growth
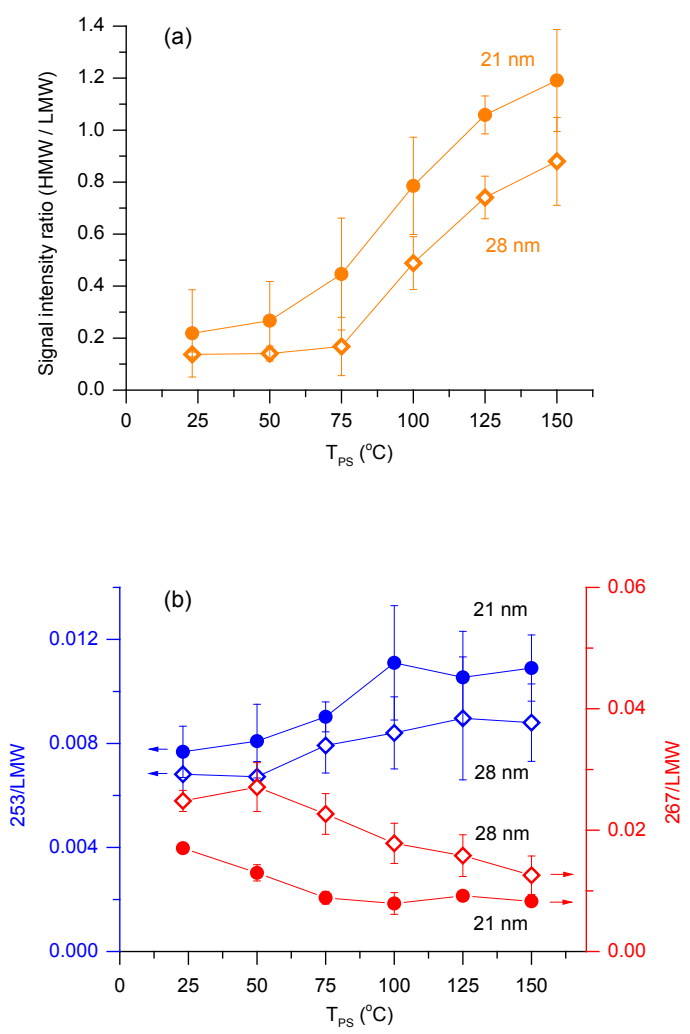

Figure 6. The DART-MS signal intensity ratio of (a) high molecular weight (HMW) products $(m / z 420-580)$ to low molecular weight (LMW) products $(m / z, 200-350)$ and (b) products at $m / z 253$ (left $y$ axis) and $m / z 267$ (right $y$ axis) to LMW products $(m / z 200-350)$ for $\alpha$-cedrene SOA particles. The data represent particles with $\bar{D}_{\mathrm{g}, \mathrm{S}}$ of $21 \mathrm{~nm}$ (solid circles) and $28 \mathrm{~nm}$ (open diamonds) at different particle stream temperatures $\left(T_{\mathrm{PS}}\right)$. Error bars are $\pm 1 \sigma$.

rather than to initial particle formation. This is not necessarily surprising since the chamber-generated particles had undergone significantly more particle growth $\left(\bar{D}_{\mathrm{g}, \mathrm{N}} \sim 70 \mathrm{~nm}\right)$ than particles generated in the flow reactor $\left(\bar{D}_{\mathrm{g}, \mathrm{N}}<30 \mathrm{~nm}\right)$ which are too small to transmit through the HR-ToF-AMS lens. While bulk particle composition measurements by HRToF-AMS were limited to chamber particles, their comparison to DART-MS measurements shows that LMW components make up the majority of the particle mass at long reaction times. This highlights the value of DART-MS in accessing the markedly different compositions at varied extents of particle growth.

Figure $6 \mathrm{~b}$ shows the intensity fraction of products with peaks at $m / z 253$ or $m / z 267$ to the total LMW products $(m / z 200-350)$ at different $T_{\mathrm{PS}}$ for polydisperse $\alpha$-cedrene SOA particles, with distributions having a $\bar{D}_{\mathrm{g}, \mathrm{S}}$ centered at 21 and $28 \mathrm{~nm}$, respectively. For both distributions, the fraction of product $m / z 253$ increases with rising $T_{\mathrm{PS}}$, whereas that of product $m / z 267$ decreases with increasing $T_{\mathrm{PS}}$. The distinct temperature dependence of these two peaks may indicate that the product responsible for $m / z 253$ has a lower 
volatility than product $m / z 267$ (although a contribution from decomposition of HMW products at higher $T_{\mathrm{PS}}$ cannot be ruled out). Smaller particles tend to have a greater fraction of $m / z 253$ compared to larger particles but a lower fraction from $m / z 267$. This suggests that the species responsible for $m / z 253$ play a more important role in the early stages of particle growth, consistent with its lower volatility. Previous studies have proposed multiple isomeric structures for the product observed at $m / z 253$ including $\alpha$-cedrinic acid and 10-hydroxy- $\alpha$-norcedralic acid (Jaoui et al., 2004, 2013; Reinnig et al., 2009; Yao et al., 2014; Zhao et al., 2016). Using the EVAPORATION model (Compernolle et al., 2011), the $P_{\text {sat }}$ of $\alpha$-cedrinic acid and 10-hydroxy- $\alpha$-norcedralic acid are estimated to be $2.4 \times 10^{-12}$ and $5.1 \times 10^{-11} \mathrm{~atm}$, respectively, and the $P_{\text {sat }}$ of the structures proposed for $\mathrm{m} / \mathrm{z} 267$ is estimated to be $(0.39-3.1) \times 10^{-11}$ atm (Zhao et al., 2016). Therefore, $\alpha$-cedrinic acid is likely the dominant structure for the product $m / z 253$ because it has the lowest $P_{\text {sat }}$ out of the two isomeric structures at $m / z, 253$ and also has a lower $P_{\text {sat }}$ than the product at $m / z 267$. This illustrates that DART-MS measurements may help resolve structural isomers of some products by providing information on their volatility.

\section{Conclusions}

DART-MS was successfully applied to the real-time study of the reaction of submicron diacid particles with gas-phase amines and to online measurement of the chemical composition of nanometer-sized SOA particles from ozonolysis of $\alpha$-cedrene. The reactivity of $\mathrm{C}_{3}-\mathrm{C}_{7}$ diacid particles toward TMA and BA exhibits a clear alternation between the odd and even carbon numbers. Calibrations using known aminediacid mixtures enable the determination of the ratios of the base to diacid in reacted particles. The relative increase in these ratios for DART-MS, compared to those derived by HR-ToF-MS, was used to estimate the probe depth of DARTMS. It is shown that DART-MS mainly probes the surface layer of the particles, in agreement with other studies on different systems. Results for $\alpha$-cedrene SOA particles show that HMW products are a major component of the smaller particles, consistent with these products playing an important role in initial particle formation (Zhao et al., 2016). Vaporization of particles at different temperatures before introduction into the DART ionization region permits the characterization of isomeric structures of SOA particles based on their volatility. All of these studies were carried out under dry conditions. The presence of water vapor would be expected to influence some of the physical and chemical processes involved in both systems. This remains to be investigated.

Some challenges remain in applying DART-MS, for example, quantification of individual compounds. While relative concentrations can be determined by utilizing an internal (Zhou et al., 2015; Schilling Fahnestock et al., 2015) or external standard (as shown for the amine-diacid system in our present study), this assumes that DART-MS has the same sensitivity for the standards and the analytes. This might not hold for SOA particles that consist of a complex mixture of organic compounds with a wide diversity of functionality and polarity. In addition, internal standards need to be well mixed with the sample, which can be difficult if the standard and analyte recrystallize separately. Furthermore, the standard configuration for DART-MS at present operates in an open environment, so the amount of the analyte actually sampled by the MS may not be well controlled. As with many other ambient ionization techniques, caution is warranted with respect to possible oxidation by $\mathrm{OH}$ and other reactive species generated in the source.

However, this study, in combination with previous work (Nah et al., 2013; Chan et al., 2013, 2014; Zhou et al., 2015; Schilling Fahnestock et al., 2015; Davies and Wilson, 2015; Zhao et al., 2016), demonstrates that DART-MS is a very useful complement to ESI-MS and other mass spectrometric techniques for the analysis of complex atmospherically relevant systems. Combined with temperature studies, it can provide depth information on spatially heterogeneous particles and potentially differentiate between isobaric compounds of different volatility.

Data availability. The data are available from the authors upon request.

\section{The Supplement related to this article is available online at doi:10.5194/amt-10-1373-2017-supplement.}

Competing interests. The authors declare that they have no conflict of interest.

Acknowledgements. This work was supported by the National Science Foundation (grant nos. 1207112, 1404233, and 1443140) and the NSF Major Research Instrumentation (MRI) program (grant nos. 1337080 and 0923323). The authors would like to thank Kristine Arquero for assistance with the TMA permeation tube and measurements of the gas-phase TMA concentration.

Edited by: H. Herrmann

Reviewed by: two anonymous referees

\section{References}

Aljawhary, D., Lee, A. K. Y., and Abbatt, J. P. D.: High-resolution chemical ionization mass spectrometry (ToF-CIMS): application to study SOA composition and processing, Atmos. Meas. Tech., 6, 3211-3224, doi:10.5194/amt-6-3211-2013, 2013.

Angelino, S., Suess, D. T., and Prather, K. A.: Formation of aerosol particles from reactions of secondary and tertiary alkylamines: 
characterization by aerosol time-of-flight mass spectrometry, Environ. Sci. Technol., 35, 3130-3138, 2001.

Bilde, M., Svenningsson, B., Monster, J., and Rosenorn, T.: Evenodd alternation of evaporation rates and vapor pressures of $\mathrm{C}_{3}$ $\mathrm{C}_{9}$ dicarboxylic acid aerosols, Environ. Sci. Technol., 37, 13711378, 2003.

Bilde, M., Barsanti, K., Booth, M., Cappa, C. D., Donahue, N. M., Emanuelsson, E. U., McFiggans, G., Krieger, U. K., Marcolli, C., Tropping, D., Ziemann, P., Barley, M., Clegg, S., DennisSmither, B., Hallquist, M., Hallquist, A. M., Khlystov, A., Kulmala, M., Mogensen, D., Percival, C. J., Pope, F., Reid, J. P., da Silva, M. A. V. R., Rosenoern, T., Salo, K., Soonsin, V. P., YliJuuti, T., Prisle, N. L., Pagels, J., Rarey, J., Zardini, A. A., and Riipinen, I.: Saturation vapor pressures and transition enthalpies of low-volatility organic molecules of atmospheric relevance: from dicarboxylic acids to complex mixtures, Chem. Rev., 115, 41154156, 2015.

Bruns, E. A., Greaves, J., and Finlayson-Pitts, B. J.: Measurement of vapor pressures and heats of sublimation of dicarboxylic acids using atmospheric solids analysis probe mass spectrometry, J. Phys. Chem. A., 116, 5900-5909, 2012.

Bzdek, B. R., Lawler, M. J., Horan, A. J., Pennington, M. R., DePalma, J. W., Zhao, J., Smith, J. N., and Johnston, M. V.: Molecular constraints on particle growth during new particle formation, Geophys. Res. Lett., 41, 6045-6054, 2014.

Canagaratna, M. R., Jimenez, J. L., Kroll, J. H., Chen, Q., Kessler, S. H., Massoli, P., Hildebrandt Ruiz, L., Fortner, E., Williams, L. R., Wilson, K. R., Surratt, J. D., Donahue, N. M., Jayne, J. T., and Worsnop, D. R.: Elemental ratio measurements of organic compounds using aerosol mass spectrometry: characterization, improved calibration, and implications, Atmos. Chem. Phys., 15, 253-272, doi:10.5194/acp-15-253-2015, 2015.

Cappa, C. D., Lovejoy, E. R., and Ravishankara, A. R.: Determination of evaporation rates and vapor pressures of very low volatility compounds: a study of the $\mathrm{C}_{4}-\mathrm{C}_{10}$ and $\mathrm{C}_{12}$ dicarboxylic acids, J. Phys. Chem. A., 111, 3099-3109, 2007.

Chan, M. N., Nah, T., and Wilson, K. R.: Real time in situ chemical characterization of sub-micron organic aerosols using direct analysis in real time mass spectrometry (DART-MS): the effect of aerosol size and volatility, Analyst, 138, 3749-3757, 2013.

Chan, M. N., Zhang, H. F., Goldstein, A. H., and Wilson, K. R.: Role of water and phase in the heterogeneous oxidation of solid and aqueous succinic acid aerosol by hydroxyl radicals, J. Phys. Chem. C., 118, 28978-28992, 2014.

Chen, H., Venter, A., and Cooks, R. G.: Extractive electrospray ionization for direct analysis of undiluted urine, milk and other complex mixtures without sample preparation, Chem. Commun., 2042-2044, doi:10.1039/B602614A, 2006.

Chen, H., Sun, Y., Wortmann, A., Gu, H., and Zenobi, R.: Differentiation of maturity and quality of fruit using noninvasive extractive electrospray ionization quadrupole time-of-flight mass spectrometry, Anal. Chem., 79, 1447-1455, 2007.

Chen, H., Varner, M. E., Gerber, R. B., and Finlayson-Pitts, B. J.: Reactions of methanesulfonic acid with amines and ammonia as a source of new particles in air, J. Phys. Chem. B., 120, 15261536, 2016.

Chingin, K., Gamez, G., Chen, H., Zhu, L., and Zenobi, R.: Rapid classification of perfumes by extractive electrospray ionization mass spectrometry (EESI-MS), Rapid Commun. Mass Sp., 22, 2009-2014, 2008.

Cody, R. B., Laramee, J. A., and Durst, H. D.: Versatile new ion source for the analysis of materials in open air under ambient conditions, Anal. Chem., 77, 2297-2302, 2005.

Compernolle, S., Ceulemans, K., and Müller, J.-F.: EVAPORATION: a new vapour pressure estimation methodfor organic molecules including non-additivity and intramolecular interactions, Atmos. Chem. Phys., 11, 9431-9450, doi:10.5194/acp-119431-2011, 2011.

Davies, J. F. and Wilson, K. R.: Nanoscale interfacial gradients formed by the reactive uptake of $\mathrm{OH}$ radicals onto viscous aerosol surfaces, Chem. Sci., 6, 7020-7027, 2015.

Dawson, M. L., Varner, M. E., Perraud, V., Ezell, M. J., Gerber, R. B., and Finlayson-Pitts, B. J.: Simplified mechanism for new particle formation from methanesulfonic acid, amines, and water via experiments and $a b$ initio calculations, P. Natl. Acad. Sci. USA, 109, 18719-18724, 2012.

Dawson, M. L., Perraud, V., Gomez, A., Arquero, K. D., Ezell, M. J., and Finlayson-Pitts, B. J.: Measurement of gas-phase ammonia and amines in air by collection onto an ion exchange resin and analysis by ion chromatography, Atmos. Meas. Tech., 7, 27332744, doi:10.5194/amt-7-2733-2014, 2014.

DeCarlo, P. F., Kimmel, J. R., Trimborn, A., Northway, M. J., Jayne, J. T., Aiken, A. C., Gonin, M., Fuhrer, K., Horvath, T., Docherty, K. S., Worsnop, D. R., and Jimenez, J. L.: Field-deployable, high-resolution, time-of-flight aerosol mass spectrometer, Anal. Chem., 78, 8281-8289, 2006.

De Haan, D. O., Hawkins, L. N., Kononenko, J. A., Turley, J. J., Corrigan, A. L., Tolbert, M. A., and Jimenez, J. L.: Formation of nitrogen-containing oligomers by methylglyoxal and amines in simulated evaporating cloud droplets, Environ. Sci. Technol., 45, 984-991, 2011.

de Semainville, P. G., D'Anna, B., and George, C.: Aqueous phase reactivity of nitrate radicals $\left(\mathrm{NO}_{3}\right)$ toward dicarboxylic acids, $\mathrm{Z}$. Phys. Chem., 224, 1247-1260, 2010.

Doezema, L., Longin, T., Cody, W., Perraud, V., Dawson, M. L., Ezell, M. J., Greaves, J., Johnson, K. R., and Finlayson-Pitts, B. $\mathrm{J}$.: Analysis of secondary organic aerosols in air using extractive electrospray ionization mass spectrometry (EESI-MS), RSC Adv., 2, 2930-2938, 2012.

Duporte, G., Parshintsev, J., Barreira, L. M. F., Hartonen, K., Kulmala, M., and Riekkola, M. L.: Nitrogen-containing low volatile compounds from pinonaldehyde-dimethylamine reaction in the atmosphere: A laboratory and field study, Environ. Sci. Technol., 50, 4693-4700, 2016.

Ervens, B., Turpin, B. J., and Weber, R. J.: Secondary organic aerosol formation in cloud droplets and aqueous particles (aqSOA): a review of laboratory, field and model studies, Atmos. Chem. Phys., 11, 11069-11102, doi:10.5194/acp-1111069-2011, 2011.

Fairhurst, M. C., Ezell, M. J., Kidd, C., Lakey, P. S. J., Shiraiwa, M., and Finlayson-Pitts, B. J.: Kinetics, mechanisms, and ionic liquids in the uptake of n-butylamine onto low molecular weight dicarboxylic acids, Phys. Chem. Chem. Phys., 19, 4827-4839, 2017.

Farmer, D. K., Cappa, C. D., and Kreidenweis, S. M.: Atmospheric processes and their controlling influence on cloud condensation nuclei activity, Chem. Rev., 115, 4199-4217, 2015. 
Finlayson-Pitts, B. J. and Pitts, J. N.: Chemistry of the Upper and Lower Atmosphere : Theory, Experiments, and Applications, Academic Press, San Diego, 2000.

Gallimore, P. J. and Kalberer, M.: Characterizing an extractive electrospray ionization (EESI) source for the online mass spectrometry analysis of organic aerosols, Environ. Sci. Technol., 47, 7324-7331, 2013.

Gao, Y. Q., Hall, W. A., and Johnston, M. V.: Molecular composition of monoterpene secondary organic aerosol at low mass loading, Environ. Sci. Technol., 44, 7897-7902, 2010.

Gard, E., Mayer, J. E., Morrical, B. D., Dienes, T., Fergenson, D. P., and Prather, K. A.: Real-time analysis of individual atmospheric aerosol particles: design and performance of a portable ATOFMS, Anal. Chem., 69, 4083-4091, 1997.

Ge, X. L., Wexler, A. S., and Clegg, S. L.: Atmospheric amines part I. A review, Atmos. Environ., 45, 524-546, 2011.

George, C., Ammann, M., D'Anna, B., Donaldson, D. J., and Nizkorodov, S. A.: Heterogeneous Photochemistry in the Atmosphere, Chem. Rev., 115, 4218-4258, 2015.

Glasius, M. and Goldstein, A. H.: Recent discoveries and future challenges in atmospheric organic chemistry, Environ. Sci. Technol., 50, 2754-2764, 2016.

Gomez-Hernandez, M., McKeown, M., Secrest, J., Marrero-Ortiz, W., Lavi, A., Rudich, Y., Collins, D. R., and Zhang, R. Y.: Hygroscopic characteristics of alkylaminium carboxylate aerosols, Environ. Sci. Technol., 50, 2292-2300, 2016.

Griffiths, P. T., Badger, C. L., Cox, R. A., Folkers, M., Henk, H. H., and Mentel, T. F.: Reactive uptake of $\mathrm{N}_{2} \mathrm{O}_{5}$ by aerosols containing dicarboxylic acids. Effect of particle phase, composition, and nitrate content, J. Phys. Chem. A., 113, 5082-5090, 2009.

Gross, J. H.: Direct analysis in real time-a critical review on DARTMS, Anal. Bioanal. Chem., 406, 63-80, 2014.

Hallquist, M., Wenger, J. C., Baltensperger, U., Rudich, Y., Simpson, D., Claeys, M., Dommen, J., Donahue, N. M., George, C., Goldstein, A. H., Hamilton, J. F., Herrmann, H., Hoffmann, T., Iinuma, Y., Jang, M., Jenkin, M. E., Jimenez, J. L., Kiendler-Scharr, A., Maenhaut, W., McFiggans, G., Mentel, Th. F., Monod, A., Prévôt, A. S. H., Seinfeld, J. H., Surratt, J. D., Szmigielski, R., and Wildt, J.: The formation, properties and impact of secondary organic aerosol: current and emerging issues, Atmos. Chem. Phys., 9, 5155-5236, doi:10.5194/acp-9-51552009, 2009.

Herrmann, H., Schaefer, T., Tilgner, A., Styler, S. A., Weller, C., Teich, M., and Otto, T.: Tropospheric aqueous-phase chemistry: kinetics, mechanisms, and its coupling to a changing gas phase, Chem. Rev., 115, 4259-4334, 2015.

Horan, A. J., Gao, Y. Q., Hall, W. A., and Johnston, M. V.: Online characterization of particles and gases with an ambient electrospray ionization source, Anal. Chem., 84, 9253-9258, 2012.

Huey, L. G.: Measurement of trace atmospheric species by chemical ionization mass spectrometry: speciation of reactive nitrogen and future directions, Mass Spectrom. Rev., 26, 166-184, 2007.

Jackson, A. U., Werner, S. R., Talaty, N., Song, Y., Campbell, K., Cooks, R. G., and Morgan, J. A.: Targeted metabolomic analysis of Escherichia coli by desorption electrospray ionization and extractive electrospray ionization mass spectrometry, Anal. Biochem., 375, 272-281, 2008.
Jaoui, M., Sexton, K. G., and Kamens, R. M.: Reaction of $\alpha$-cedrene with ozone: mechanism, gas and particulate products distribution, Atmos. Environ., 38, 2709-2725, 2004.

Jaoui, M., Kleindienst, T. E., Docherty, K. S., Lewandowski, M., and Offenberg, J. H.: Secondary organic aerosol formation from the oxidation of a series of sesquiterpenes: $\alpha$-cedrene, $\beta$ caryophyllene, $\alpha$-humulene and $\alpha$-farnesene with $\mathrm{O}_{3}, \mathrm{OH}$ and $\mathrm{NO}_{3}$ radicals, Environ. Chem., 10, 178-193, 2013.

Jimenez, J. L., Canagaratna, M. R., Donahue, N. M., Prevot, A. S. H., Zhang, Q., Kroll, J. H., DeCarlo, P. F., Allan, J. D., Coe, H., Ng, N. L., Aiken, A. C., Docherty, K. S., Ulbrich, I. M., Grieshop, A. P., Robinson, A. L., Duplissy, J., Smith, J. D., Wilson, K. R., Lanz, V. A., Hueglin, C., Sun, Y. L., Tian, J., Laaksonen, A., Raatikainen, T., Rautiainen, J., Vaattovaara, P., Ehn, M., Kulmala, M., Tomlinson, J. M., Collins, D. R., Cubison, M J., Dunlea, E. J., Huffman, J. A., Onasch, T. B., Alfarra, M. R., Williams, P. I., Bower, K., Kondo, Y., Schneider, J., Drewnick, F., Borrmann, S., Weimer, S., Demerjian, K., Salcedo, D., Cottrell, L., Griffin, R., Takami, A., Miyoshi, T., Hatakeyama, S., Shimono, A., Sun, J. Y., Zhang, Y. M., Dzepina, K., Kimmel, J. R., Sueper, D., Jayne, J. T., Herndon, S. C., Trimborn, A. M., Williams, L. R., Wood, E. C., Middlebrook, A. M., Kolb, C. E., Baltensperger, U., and Worsnop, D. R.: Evolution of organic aerosols in the atmosphere, Science, 326, 1525-1529, 2009.

Kawamura, K. and Bikkina, S.: A review of dicarboxylic acids and related compounds in atmospheric aerosols: molecular distributions, sources and transformation, Atmos. Res., 170, 140-160, 2016.

Kolesar, K. R., Li, Z. Y., Wilson, K. R., and Cappa, C. D.: Heatinginduced evaporation of nine different secondary organic aerosol types, Environ. Sci. Technol., 49, 12242-12252, 2015.

Kroll, J. H. and Seinfeld, J. H.: Chemistry of secondary organic aerosol: formation and evolution of low-volatility organics in the atmosphere, Atmos. Environ., 42, 3593-3624, 2008.

Kulmala, M., Petaja, T., Ehn, M., Thornton, J., Sipila, M., Worsnop, D. R., and Kerminen, V. M.: Chemistry of atmospheric nucleation: on the recent advances on precursor characterization and atmospheric cluster composition in connection with atmospheric new particle formation, Annu. Rev. Phys. Chem., 65, 21-37, 2014.

Laskin, A., Laskin, J., and Nizkorodov, S. A.: Mass spectrometric approaches for chemical characterisation of atmospheric aerosols: critical review of the most recent advances, Environ. Chem., 9, 163-189, 2012.

Laskin, A., Laskin, J., and Nizkorodov, S. A.: Chemistry of atmospheric brown carbon, Chem. Rev., 115, 4335-4382, 2015.

Laskin, J., Laskin, A., and Nizkorodov, S. A.: New mass spectrometry techniques for studying physical chemistry of atmospheric heterogeneous processes, Int. Rev. Phys. Chem., 32, 128-170, 2013.

Lavi, A., Segre, E., Gomez-Hernandez, M., Zhang, R. Y., and Rudich, Y.: Volatility of atmospherically relevant alkylaminium carboxylate salts, J. Phys. Chem. A., 119, 4336-4346, 2015.

Law, W. S., Wang, R., Hu, B., Berchtold, C., Meier, L., Chen, H. W., and Zenobi, R.: On the mechanism of extractive electrospray ionization, Anal. Chem., 82, 4494-4500, 2010.

Lide, D. R.: CRC Handbook of Chemistry and Physics, CRC press, 2004. 
Liu, Y. C., Ma, Q. X., and He, H.: Heterogeneous uptake of amines by citric acid and humic acid, Environ. Sci. Technol., 46, 1111211118, 2012.

Lopez-Hilfiker, F. D., Mohr, C., Ehn, M., Rubach, F., Kleist, E., Wildt, J., Mentel, Th. F., Lutz, A., Hallquist, M., Worsnop, D., and Thornton, J. A.: A novel method for online analysis of gas and particle composition: description and evaluation of a Filter Inlet for Gases and AEROsols (FIGAERO), Atmos. Meas. Tech., 7, 983-1001, doi:10.5194/amt-7-983-2014, 2014.

Moise, T., Flores, J. M., and Rudich, Y.: Optical properties of secondary organic aerosols and their changes by chemical processes, Chem. Rev., 115, 4400-4439, 2015.

Müller, C., Iinuma, Y., Karstensen, J., van Pinxteren, D., Lehmann, S., Gnauk, T., and Herrmann, H.: Seasonal variation of aliphatic amines in marine sub-micrometer particles at the Cape Verde islands, Atmos. Chem. Phys., 9, 9587-9597, doi:10.5194/acp-99587-2009, 2009a.

Muller, L., Reinnig, M. C., Hayen, H., and Hoffmann, T.: Characterization of oligomeric compounds in secondary organic aerosol using liquid chromatography coupled to electrospray ionization Fourier transform ion cyclotron resonance mass spectrometry, Rapid Commun. Mass Sp., 23, 971-979, 2009b.

Murphy, D. M. and Thomson, D. S.: Laser ionization massspectroscopy of single aerosol-particles, Aerosol Sci. Tech., 22, 237-249, 1995

Nah, T., Chan, M., Leone, S. R., and Wilson, K. R.: Real time in situ chemical characterization of submicrometer organic particles using direct analysis in real time-mass spectrometry, Anal. Chem., 85, 2087-2095, 2013.

Ng, N. L., Canagaratna, M. R., Zhang, Q., Jimenez, J. L., Tian, J., Ulbrich, I. M., Kroll, J. H., Docherty, K. S., Chhabra, P. S., Bahreini, R., Murphy, S. M., Seinfeld, J. H., Hildebrandt, L., Donahue, N. M., DeCarlo, P. F., Lanz, V. A., Prévôt, A. S. H., Dinar, E., Rudich, Y., and Worsnop, D. R.: Organic aerosol components observed in Northern Hemispheric datasets from Aerosol Mass Spectrometry, Atmos. Chem. Phys., 10, 46254641, doi:10.5194/acp-10-4625-2010, 2010.

Nizkorodov, S. A., Laskin, J., and Laskin, A.: Molecular chemistry of organic aerosols through the application of high resolution mass spectrometry, Phys. Chem. Chem. Phys., 13, 3612-3629, 2011.

Noziere, B., Kaberer, M., Claeys, M., Allan, J., D’Anna, B., Decesari, S., Finessi, E., Glasius, M., Grgic, I., Hamilton, J. F., Hoffmann, T., Iinuma, Y., Jaoui, M., Kahnt, A., Kampf, C. J., Kourtchev, I., Maenhaut, W., Marsden, N., Saarikoski, S., Schnelle-Kreis, J., Surratt, J. D., Szidat, S., Szmigielski, R., and Wisthaler, A.: The molecular identification of organic compounds in the atmosphere: state of the art and challenges, Chem. Rev., 115, 3919-3983, 2015.

Powelson, M. H., Espelien, B. M., Hawkins, L. N., Galloway, M. M., and De Haan, D. O.: Brown carbon formation by aqueousphase carbonyl compound reactions with amines and ammonium sulfate, Environ. Sci. Technol., 48, 985-993, 2014.

Pratt, K. A. and Prather, K. A.: Mass spectrometry of atmospheric aerosols-recent developments and applications, Part 1: off-line mass spectrometry techniques, Mass Spectrom. Rev., 31, 1-16, 2012a.

Pratt, K. A. and Prather, K. A.: Mass spectrometry of atmospheric aerosols-recent developments and applications, Part 2: on-line mass spectrometry techniques, Mass Spectrom. Rev., 31, 17-48, 2012b.

Reinnig, M. C., Warnke, J., and Hoffmann, T.: Identification of organic hydroperoxides and hydroperoxy acids in secondary organic aerosol formed during the ozonolysis of different monoterpenes and sesquiterpenes by on-line analysis using atmospheric pressure chemical ionization ion trap mass spectrometry, Rapid Commun. Mass Sp., 23, 1735-1741, 2009.

Ruehl, C. R. and Wilson, K. R.: Surface organic monolayers control the hygroscopic growth of submicrometer particles at high relative humidity, J. Phys. Chem. A., 118, 3952-3966, 2014.

Schilling Fahnestock, K. A., Yee, L. D., Loza, C. L., Coggon, M. M., Schwantes, R., Zhang, X., Dalleska, N. F., and Seinfeld, J. H.: Secondary organic aerosol composition from $\mathrm{C}_{12}$ alkanes, J. Phys. Chem. A., 119, 4281-4297, 2015.

Smith, J. N., Moore, K. F., McMurry, P. H., and Eisele, F. L.: Atmospheric measurements of sub-20 nm diameter particle chemical composition by thermal desorption chemical ionization mass spectrometry, Aerosol Sci. Tech., 38, 100-110, 2004.

Sun, Y. R., Chang, W., Ji, H. W., Chen, C. C., Ma, W. H., and Zhao, J. C.: An unexpected fluctuating reactivity for odd and even carbon numbers in the $\mathrm{TiO}_{2}$-based photocatalytic decarboxylation of $\mathrm{C}_{2}-\mathrm{C}_{6}$ dicarboxylic acids, Chem.-Eur. J., 20, 1861-1870, 2014.

Taketani, F., Kanaya, Y., and Akimoto, H.: Kinetic studies of heterogeneous reaction of $\mathrm{HO}_{2}$ radical by dicarboxylic acid particles, Int. J. Chem. Kinet., 45, 560-565, 2013.

Thalladi, V. R., Nusse, M., and Boese, R.: The melting point alternation in $\alpha, \omega$-alkanedicarboxylic acids, J. Am. Chem. Soc., 122, 9227-9236, 2000

Tobias, H. J., Kooiman, P. M., Docherty, K. S., and Ziemann, P. J.: Real-time chemical analysis of organic aerosols using a thermal desorption particle beam mass spectrometer, Aerosol Sci. Tech., 33, 170-190, 2000.

Wang, R., Grohn, A. J., Zhu, L., Dietiker, R., Wegner, K., Gunther, D., and Zenobi, R.: On the mechanism of extractive electrospray ionization (EESI) in the dual-spray configuration, Anal. Bioanal. Chem., 402, 2633-2643, 2012.

Winkler, P. M., Ortega, J., Karl, T., Cappellin, L., Friedli, H. R., Barsanti, K., McMurry, P. H., and Smith, J. N.: Identification of the biogenic compounds responsible for sizedependent nanoparticle growth, Geophys. Res. Lett., 39, L20815, doi:10.1029/2012GL053253, 2012.

Yao, L., Ma, Y., Wang, L., Zheng, J., Khalizov, A., Chen, M. D., Zhou, Y. Y., Qi, L., and Cui, F. P.: Role of stabilized Criegee intermediate in secondary organic aerosol formation from the ozonolysis of $\alpha$-cedrene, Atmos. Environ., 94, 448-457, 2014.

Yatavelli, R. L. N., Lopez-Hilfiker, F., Wargo, J. D., Kimmel, J. R., Cubison, M. J., Bertram, T. H., Jimenez, J. L., Gonin, M., Worsnop, D. R., and Thornton, J. A.: A chemical ionization highresolution time-of-flight mass spectrometer coupled to a micro orifice volatilization impactor (MOVI-HR-ToF-CIMS) for analysis of gas and particle-phase organic species, Aerosol Sci. Tech., 46, 1313-1327, 2012.

Zelenyuk, A. and Imre, D.: Single particle laser ablation time-offlight mass spectrometer: an introduction to SPLAT, Aerosol Sci. Tech., 39, 554-568, 2005.

Zhang, H., Xie, C., Liu, Z. K., Gong, J. B., Bao, Y., Zhang, M. J., Hao, H. X., Hou, B. H., and Yin, Q. X.: Identification and molec- 
ular understanding of the odd-even effect of dicarboxylic acids aqueous solubility, Ind. Eng. Chem. Res., 52, 18458-18465, 2013.

Zhang, Q., Jimenez, J. L., Canagaratna, M. R., Allan, J. D., Coe, H., Ulbrich, I., Alfarra, M. R., Takami, A., Middlebrook, A. M., Sun, Y. L., Dzepina, K., Dunlea, E., Docherty, K., DeCarlo, P. F., Salcedo, D., Onasch, T., Jayne, J. T., Miyoshi, T., Shimono, A., Hatakeyama, S., Takegawa, N., Kondo, Y., Schneider, J., Drewnick, F., Borrmann, S., Weimer, S., Demerjian, K., Williams, P., Bower, K., Bahreini, R., Cottrell, L., Griffin, R. J., Rautiainen, J., Sun, J. Y., Zhang, Y. M., and Worsnop, D. R.: Ubiquity and dominance of oxygenated species in organic aerosols in anthropogenically-influenced Northern Hemisphere midlatitudes, Geophys. Res. Lett., 34, L13801, doi:10.1029/2007GL029979, 2007.

Zhang, R. Y., Khalizov, A., Wang, L., Hu, M., and Xu, W.: Nucleation and growth of nanoparticles in the atmosphere, Chem. Rev., 112, 1957-2011, 2012.
Zhao, Y., Wingen, L. M., Perraud, V., Greaves, J., and FinlaysonPitts, B. J.: Role of the reaction of stabilized Criegee intermediates with peroxy radicals in particle formation and growth in air, Phys. Chem. Chem. Phys., 17, 12500-12514, 2015.

Zhao, Y., Wingen, L. M., Perraud, V., and Finlayson-Pitts, B. J.: Phase, composition, and growth mechanism for secondary organic aerosol from the ozonolysis of a-cedrene, Atmos. Chem. Phys., 16, 3245-3264, doi:10.5194/acp-16-3245-2016, 2016.

Zhou, S. M., Forbes, M. W., and Abbatt, J. P. D.: Application of direct analysis in real time-mass spectrometry (DART-MS) to the study of gas-surface heterogeneous reactions: focus on ozone and PAHs, Anal. Chem., 87, 4733-4740, 2015.

Ziemann, P. J. and Atkinson, R.: Kinetics, products, and mechanisms of secondary organic aerosol formation, Chem. Soc. Rev., 41, 6582-6605, 2012. 